Devanand Gupta ${ }^{1}$

Dara John Bhaskar ${ }^{1}$

Rajendra Kumar Gupta

Ankita Jain ${ }^{1}$

Priyanka Yadav ${ }^{3}$

Deepak Ranjan Dalai ${ }^{1}$

Rajeshwar Singh ${ }^{4}$

Nisha Singh ${ }^{5}$

Varunjeet Chaudhary ${ }^{4}$

Ankit Singh ${ }^{4}$

Ankit Yadav ${ }^{4}$

Bushra Karim ${ }^{1}$

\title{
IS COMPLEMENTARY AND ALTERNATIVE MEDICINE EFFECTIVE IN JOB SATISFACTION AMONG DENTISTS WITH MUSCULOSKELETAL DISORDERS? A CROSS SECTIONAL STUDY
}

\author{
CZY MEDYCYNA KOMPLEMENTARNA I ALTERNATYWNA MA WPŁYW NA SATYSFAKCJĘ ZAWODOWA \\ DENTYSTÓW Z ZABURZENIAMI MIĘŚNIOWO-SZKIELETOWYMI? BADANIE PRZEKROJOWE
}

\author{
${ }^{1}$ Teerthankar Mahaveer Dental College and Research Centre, Moradabad, Uttar Pradesh, India \\ Department of Public Health Dentistry \\ ${ }^{2}$ Government Post Graduate College, Lansdowne, Uttrakhand, India \\ ${ }^{3}$ Rajasthan Dental College, Jaipur, India \\ Department of Public Health Dentistry \\ ${ }^{4}$ Teerthankar Mahaveer Dental College and Research Centre, Moradabad, Uttar Pradesh, India \\ Department of Orthodontics and Dentofacial Orthopedics \\ ${ }^{5}$ Buddha Institute of Dental Sciences, Bihar, India \\ Department of Pedodontics
}

\begin{abstract}
Background: Musculoskeletal disorders have serious impact on the profession of dentistry. There is common occurrence of pain due to incorrect posture in dental professionals. Complementary and alternative medicine (CAM) therapies may cast a new light on preventing and intercepting musculoskeletal disorders (MSD). An epidemiological study was conducted in an effort to contribute to the prevention of musculoskeletal disorders in dentistry. The purpose of this study was to determine the prevalence of MSD at dentists using CAM as a treatment and preventive modality for MSD and to compare job/career satisfaction between dentists who use CAM and conventional therapy (CT). Material and Methods: Dentists registered in Uttrakhand state, India, under the Dental Council of India and registered members of the Indian Dental Association, Uttrakhand branch $(\mathrm{N}=1496)$ were surveyed. Statistical analysis was conducted using SPSS 17. Results: A response rate of $84 \%(\mathrm{~N}=1257)$ was obtained, revealing that $90 \%$ $(\mathrm{N}=1131)$ had the problem of MSD. Seventy three percentage $(\mathrm{N}=826)$ of dentists with MSD reported the use of CAM and CT. Complementary and alternative medicine users reported greater overall health $(72.7 \%$ vs. $51 \%, \mathrm{p}<0.001)$, job satisfaction $(61.2 \%$ vs. $35 \%, \mathrm{p}<0.001)$ and work efficiency compared to CT users. Conclusion: Complementary and alternative medicine therapies may improve quality of life, reduce work interruption and enhance job satisfaction for dentists who suffers from MSD. Through the course of their studies, dentists should be equipped with knowledge on ergonomics and CAM therapies, such as yoga and others, to help them prevent musculoskeletal disorders more effectively. Med Pr 2014;65(3):317-323
\end{abstract}

Key words: complementary and alternative medicine, dentist, musculoskeletal disorders

\section{STRESZCZENIE}

Wstęp: Zaburzenia mięśniowo-szkieletowe znacząco wpływają na wykonywanie zawodu przez lekarzy dentystów. W tej grupie zawodowej obserwuje się powszechne występowanie bólu z powodu nieprawidłowej postawy ciała. Terapie z zakresu medycyny komplementarnej i alternatywnej (complementary and alternative medicine - CAM) mogą rzucić nowe światło na zapobieganie zaburzeniom mięśniowo-szkieletowym (musculoskeletal disorders - MSD). Celem badania było ustalenie, czy w przypadku MSD dentyści korzystają z medycyny alternatywnej. Porównano także satysfakcję zawodową dentystów, którzy stosują terapie CAM i tych korzystających z terapii konwencjonalnej. Materiał i metody: W badaniu wzięli udział dentyści zarejestrowani 
w regionie Uttrakhand (Indie) w Radzie Dentystycznej Indii i będący członkami Indyjskiego Towarzystwa Dentystycznego (oddział Uttrakhand) $(\mathrm{N}=1496)$. Analizy statystyczne przeprowadzono za pomocą pakietu SPSS 17. Wyniki: Wskaźnik odpowiedzi wyniósł 84\% $(\mathrm{N}=1257)$. Aż $90 \%(\mathrm{~N}=1131)$ respondentów cierpiało z powodu MSD. Korzystanie z CAM i terapii konwencjonalnej zgłosiło $73 \%(\mathrm{~N}=826)$ dentystów biorących udział w badaniu, u których występowały MSD. Osoby stosujące CAM w porównaniu z osobami leczącymi się konwencjonalnie zgłaszały lepszy ogólny stan zdrowia $(72,7 \%$ vs 51\%, p < 0,001), wyższy poziom satysfakcji zawodowej $(61,2 \%$ vs $35 \%, p<0,001)$ i były w stanie pracować w takim wymiarze czasu, w jakim chciały $(56,8 \%$ vs. $67 \%$, p < 0,001) Wnioski: Terapie CAM mogą poprawić jakość życia, zredukować przerwy w pracy i zwiększyć satysfakcję zawodową u dentystów cierpiących na MSD. Już na etapie studiów należy przekazać dentystom wiedzę z zakresu ergonomii oraz terapii CAM, żeby potrafili skuteczniej zapobiegać wystąpieniu zaburzeń mięśniowo-szkieletowych. Med.Pr. 2014;65(3):317-323

Słowa kluczowe: medycyna komplementarna i alternatywna, dentysta, zaburzenia mięśniowo-szkieletowe

Corresponding author / Autor do korespondencji: Devanand Gupta, Department of Public Health Dentistry, Teerthankar Mahaveer Dental College and Research Centre, Delhi Road, Moradabad, Pin code 263139, Uttar Pradesh, India, e-mail: guptaphd@ymail.com

Received: 2013, October 9; accepted: 2014, January 24

\section{INTRODUCTION}

Dental professionals often work in the same postures which are known as prolonged static postures. Contraction of most of the muscles occurs in the most comfortable seated position and the movement of joints is also less intense. Shoulder, back and neck pain occurs due to these damaging physiological changes and leads to musculoskeletal disorders. These musculoskeletal diseases, including pain, weakness and paraesthesia, are also associated with other occupations and they may affect occupational health, productivity and careers of the working population (1-4).

Musculoskeletal disorders (MSD) are injuries to the human support system that may occur due to a single or multiple traumas (5). Dentists have reported musculoskeletal disorders for decades $(6,7)$. The burden of performing repetitive and fine actions places them at a potentially higher risk of MSD than psychosocial issues (8). The physical exertion while doing clinical work is the main reason that has been linked with MSD; however, some recent studies have demonstrated that psychosocial factors are also associated with MSD. Factors leading to musculoskeletal disorders include: sitting for a long period of time, operator position, poor posture, lack of flexibility and strength, poor ergonomics and insufficient work breaks (9). Poor posture habits, like twisting, tilting sideways, bending forward, increase the likelihood of MSDs. Many conditions are associated with MSDs, like carpal tunnel syndrome that involves nerves, tendons and muscles. MSD can prevail in 2 forms: it may be mild on one hand and it can be severe and debilitating on the other hand. MSDs are an unavoidable part of the oral health care providers' lives (10). The physical burden of doing the same actions repeatedly places them at a signifi- cantly higher risk of MSD. Many dentists have reported work stress and burn-out caused by musculoskeletal disorders (11).

Job satisfaction is the indicator that may have an influence on career longevity. Job satisfaction is a strong predictor of individual happiness; it can also persuade an individual's decision to leave a profession. It has been reported that change in the work environment may increase the career longevity of dentists. Complementary and alternative medicine (CAM) is a treatment option that is considered to be a step beyond the conventional medicine. Where conventional medicine uses antagonists to combat a disease, complementary and alternative medicines use herbs, acupuncture, massage, yoga, homeopathy etc. to deal with these musculoskeletal problems $(12,13)$. There are currently no reports that link musculoskeletal pain, CAM and job satisfaction among dentists residing in Uttrakhand state, India.

As the MSDs are increasing on an alarming rate, and previous studies show a high prevalence of MSD, this study was conducted in Uttrakhand, India, with the aim to determine the prevalence of MSD in dentists using CAM therapies to manage their musculoskeletal pain and, whether CAM therapies are associated with their job satisfaction and longevity when compared to conventional therapy.

\section{MATERIAL AND METHODS}

This cross-sectional study used a survey with the approval of the Teerthankar Mahaveer University (TMU) Biomedical Institutional Review Board and meets the standards of the Declaration of Helsinki. Dentists registered under the Uttrakhand state Dental Council and current members of the Indian Dental Association (IDA) were recruited to complete a questionnaire 
based on their experience on musculoskeletal pain and the use of CAM in the management of MSDs.

\section{Development of questionnaire}

A pilot study was conducted among dentists registered under the Uttrakhand State Dental Council attending continuing education course in the state. The validity and reliability of the questionnaire were tested by running pilot tests on 30 dentists who were not included in the main study, and testing and retesting the questionnaire took place. Data collected from the pilot test was analyzed using SPSS (Statistical Package for Social Sciences). A reliability coefficient ( $\alpha$ ) of 0.80 or higher was considered acceptable. Further changes were made in questionnaire. The changes included how questions were phrased, the addition and removal of questions. Configuration of the questionnaire from paper into web based survey software was done. The final questionnaire was approved by the Institutional Review Board prior to administration.

\section{Research subjects and administration of questionnaire} All dentists who are current members of the Indian dental association Uttrakhand state branch, India, and are registered under the Dental Council of India Uttrakhand state were recruited to participate.

The final version of the questionnaire was prepared for electronic distribution. Subjects were mailed the link to their email address to complete the web-based questionnaire. One week before sending the link to the survey, subjects were sent an individual invitation to participate in the web-based survey in order to prevent emails from being identified as spam. One week later, individuals were sent another email that directed them to the website to complete the questionnaire. A reminder mail was sent to non respondents. The first reminder was sent 10 days after the first mailing, with the addition of a second reminder 2 weeks later. The final email reminder was sent 1 week before closing the study on January 31, 2012.

\section{Inclusion/exclusion criteria}

This study included all willing, registered dentists who were current members of the Indian dental association Uttrakhand state branch, India, and registered under the Dental Council of India Uttrakhand state with email addresses $(\mathrm{N}=1497)$. Dentists who participated in the pilot study, dental students, members of the general public, dental hygienists, dental assistants and others who are not registered dentist were excluded.

\section{Contents of questionnaire}

The questionnaire consisted of 7 domains:

1. Respondents who have experienced any sort of MSD in the past 2 years.

2. Pain management techniques adopted by the dentists for MSDs.

3. How they used conventional therapies.

4. What CAM practices they used and what therapies they used related to it.

5. Views about the use of CAM over conventional therapies.

6. Job satisfaction.

7. Demographics of the responding dentist.

\section{Data analysis}

Statistical analysis was conducted using SPSS 17. Univariate and bivariate analyses were performed to determine demographic information; frequently reported locations of pain, number of respondents that used CAM or conventional therapies, types of CAM or conventional therapies most frequently used, work disruption caused by MSD and job satisfaction. The t-tests were used to determine the opinions about CAM and conventional therapies for MSD management. Chisquare analysis was used to investigate the relationship between having MSD and using CAM therapies.

\section{RESULTS}

Web-based questionnaires were sent to 1497 people and $84 \%$ dentists replied to the survey $(\mathrm{N}=1257)$. Demographic characteristics showed that the majority of the study population were males $(77.7 \%)$ and they primarily worked in general dental offices (71.3\%). Ninety percent of the dentists $(\mathrm{N}=1131)$ reported having MSD with the mean duration of pain 5.3 years $($ median $=3.7$ ). Other demographic characteristics of respondents are presented in Table 1.

Figure 1 shows the most frequently reported locations of pain among dentist. The most common sites of pain were neck and lower back. The odds of temporarily quitting the job for 2 months were 4 times more in individuals who used both CAM and conventional therapy than those who used CAM therapies alone $(\mathrm{OR}=5.3,95 \% \mathrm{CI}: 2.7-22.01)$. Figure 2 depicts different forms of CAM therapies used among dentists. Seventy three percent $(\mathrm{N}=826)$ of respondents reported using both CAM and conventional therapies to manage MSD. Among the respondents who suffered from MSD, $57 \%(\mathrm{~N}=645)$ used CAM therapies alo- 
Table 1. Characteristics of the study group

Tabela 1. Charakterystyka badanej grupy

\begin{tabular}{cc} 
Variable & \multicolumn{2}{c}{ Respondents } \\
Zmienna & \multicolumn{2}{c}{ Badani } \\
\cline { 2 - 2 }$(\mathrm{N}=1257)$ & $\mathrm{n} \%$ \\
\hline
\end{tabular}

Age [years] / Wiek [w latach]

$\begin{array}{lll}23-30 & 188 & 16.0 \\ 31-45 & 365 & 29.0 \\ 46-55 & 327 & 26.0 \\ >56 & 377 & 30.0\end{array}$

Gender / Płeć

male / mężczyzna

female / kobieta

Education / Wykształcenie

bachelor's / licencjat

1094

87.1

master's / magisterium

162

12.9

Year of obtaining diploma / Rok uzyskania dyplomu

before / przed 1980

1980-1999

2000-2012

Seniority as a dentist (years) / Staż pracy

jako dentysta [w latach]

$<1$
$1-5$
$6-10$
$11-20$
$>20$

Practice type / Typ praktyki

general practice / ogólna

specialized practice / specjalistyczna

General health status / Ogólny stan zdrowia

excellent/good / doskonały/dobry

ne, 38\% $(\mathrm{N}=430)$ used conventional therapies alone and $5 \%(\mathrm{~N}=57)$ used no therapies.

There was a significant difference between dentists who used CAM therapies and conventional therapies for MSD $(\mathrm{t}(357)=4.13, \mathrm{p}=0.007)$. Dentists who reported pain had higher levels of agreement with the CAM-related opinion statements in the questionnaire.

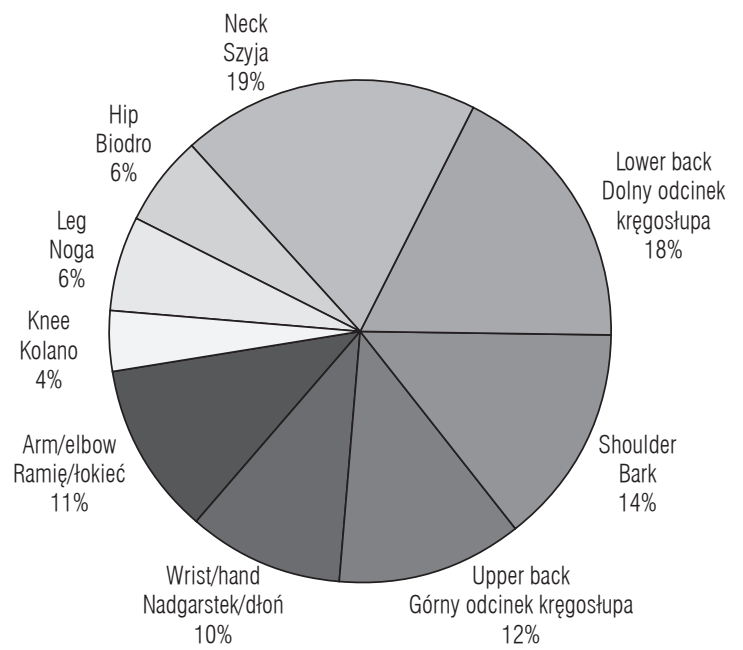

Fig. 1. Location of pain reported by respondents

Ryc. 1. Lokalizacja bólu zgłaszanego przez badanych dentystów

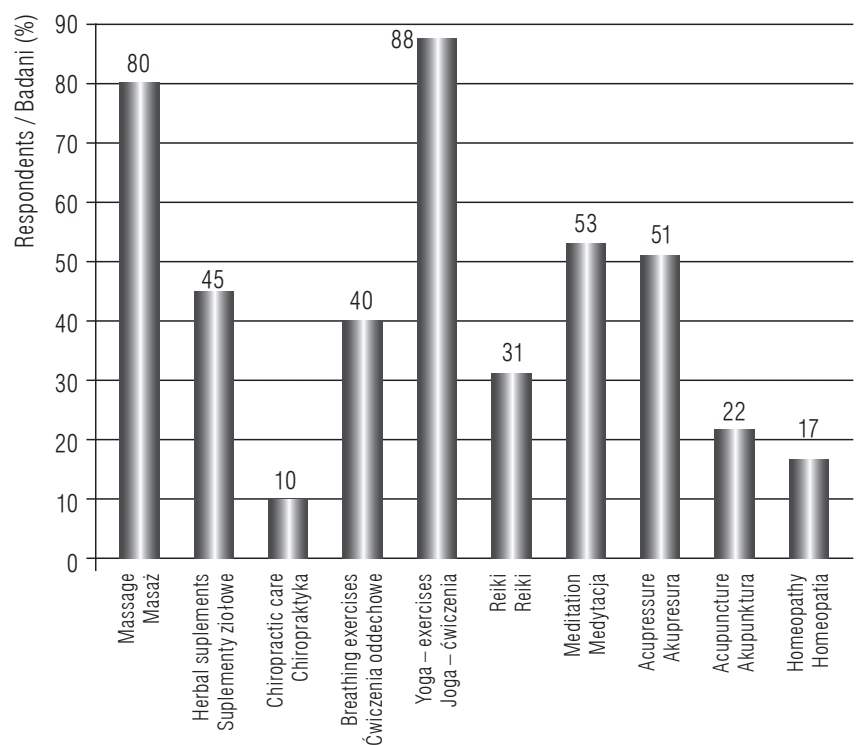

Fig. 2. Different forms of CAM used among respondents with chronic pain

Ryc. 2. Różne formy terapii komplementarnej i alternatywnej stosowane przez respondentów z chronicznym bólem

Dentists with MSD were 4 times more likely to agree that CAM therapies were better for MSD management $(\mathrm{OR}=4.2,95 \% \mathrm{CI}: 1.9$ to 5.6$)$ than those with no pain, and were 3 times more likely to use CAM therapies for MSD management (OR $=3.3$, 95\% CI: $1.3-7.1)$. Table 2 shows respondents relation between CAM therapies and conventional therapies and their effect on career satisfaction. Dentists who used CAM therapies for MSD had significantly higher odds of satisfaction with their career when compared to conventional therapies users $(\mathrm{OR}=3.1,95 \% \mathrm{CI}=1.3-5.9)$. 
Table 2. Influence of conventional therapy and CAM therapy on career satisfaction ${ }^{a}$

Tabela 2. Wpływ stosowania terapii konwencjonalnej lub terapii CAM na satysfakcję zawodową ${ }^{a}$

\begin{tabular}{|c|c|c|c|}
\hline $\begin{array}{l}\text { Variable } \\
\text { Zmienna }\end{array}$ & $\begin{array}{c}\text { CAM vs. conventional } \\
\text { therapy } \\
\text { CAM vs terapia } \\
\text { konwencjonalna } \\
\text { (M) }\end{array}$ & $t(d f)$ & $\begin{array}{c}\text { CAM vs. conventional } \\
\text { therapy } \\
\text { CAM vs terapia } \\
\text { konwencjonalna } \\
\text { (OR) }\end{array}$ \\
\hline Contribution to my career/satisfaction / Wpływ na moją karierę/satysfakcję & 0.41 & $6.18(369)^{*}$ & 3.71 \\
\hline Contribution to my career longevity / Wkład w długość trwania mojej kariery & 0.68 & $8.19(378)^{*}$ & 2.77 \\
\hline Contribution to my health / Wpływ na moje zdrowie & 0.55 & $7.59(375)^{\star}$ & 2.12 \\
\hline Increased my working efficiency / Wzrost mojej wydajności pracy & 0.22 & $5.91(338)^{*}$ & 3.71 \\
\hline Job satisfaction / Satysfakcja zawodowa & 0.54 & $7.29(359)^{*}$ & 2.39 \\
\hline
\end{tabular}

CAM - complementary and alternative medicine / medycyna komplementarna i alternatywna

${ }^{a}$ Likert scale was used (range: 1 - strongly agree, 5 - strongly disagree) / Zastosowano skalę Likerta (zakres: 1 - zdecydowanie się zgadzam, 5 - zdecydowanie się nie zgadzam). $\mathrm{t}(\mathrm{df})$ - degree of freedom at $\mathrm{t}$ distribution, $\mathrm{OR}$ - odds ratio / iloraz szans. ${ }^{*} \mathrm{p}<0.001$.

Investigators looked at the reported use of CAM therapies and found that older individuals were more likely to use CAM when compared to younger individuals $(\mathrm{OR}=1.16,95 \%$ CI: 1.009-1.093). Non-CAM users were more likely to report lesser MSD management when compared to CAM users ( $\mathrm{OR}=3.5,95 \% \mathrm{CI}: 1.4-3.7)$. Gender, race, type of degree earned and number of years practicing were not statistically different among the respondents.

\section{DISCUSSION}

The motions and high degree of manual dexterity required by dentists are the main causes of MSD in the dental industry and constitute issues that need to be addressed. MSDs are synonymous with many other names, such as, cumulative trauma disorders (CTD) or even occupational overuse syndrome and are injuries that occur due to repetitive motions that gradually wear away at the body. The most common reported injuries have resulted from awkward working positions and the poor design of hand-held tooling. Complementary and alternative medicine (CAM) is a holistic approach that combines medical system with other health care systems, practices, and products. These are no part of conventional medicine. The different terms used to define treatments other than regular mainstream allopathic treatments are complementary, alternative, integrative, natural, unconventional etc. Surveys have suggested that the use of complementary and alternative medicines (CAM) is high and increasing worldwide (14).
There are different types of CAM therapies, including whole medical systems (homeopathic and naturopathic medicine), mind-body medicine (meditation, prayer and mental healing), biologically based practices (dietary supplements and herbal products), manipulative and body-based medicine (chiropractic care and massage) and energy medicine (Reiki and therapeutic touch). Musculoskeletal disorders (MSDs) are problems of musculoskeletal system that include weakness of muscles and joints, paresthesia and pain. They may include problems in ligaments, nerves, tendons, etc. and are associated with incorrect postures in different occupations. These are the most common, costly and significant problems of workplace that adversely affect productivity, occupational health and the careers of professionals. About 2 million of workers in different professions suffer from musculoskeletal disorders each year. The problems occur due to repetitive awkward postures and motions. Dental personnel have an increased risk of developing such disorders (5,15-19).

In the previous studies, CAM therapies have shown significant results in reducing the risk of musculoskeletal and other problems in general population (20-24). In our study, individuals who used CAM therapies alone were less likely to report temporarily quitting work for longer than 2 months. Therefore, dentists who use CAM therapies may reduce work interruptions caused by musculoskeletal pain. Basing on the findings of the present study, dentists who do not suffer from musculoskeletal pain experience, express higher job satisfaction when compared to those who suffer 
from MSD $(\mathrm{p}=0.001)$. Those with MSD reported that it had a negative impact on job longevity. Respondents who used CAM therapies alone were more likely to be satisfied with their career compared to those who used conventional therapies alone.

Therefore, dentists who use CAM therapies for the prevention and management of MSD may experience higher career satisfaction and longevity when compared to those using conventional therapies. The most favoured CAM therapies among participants in the current study were: yogic exercise, massage, meditation and acupressure. No effective gender comparison can be produced as the sample was predominantly male. To date, no studies have examined the use of CAM for MSD among dentists and its association with career satisfaction, so the results could not be compared with any other study. A study similar to ours also reported maximum MSD in the neck and lower back region.

In one study, more than sixty percent of individuals reported using CAM plus conventional therapies for musculoskeletal pain (21). The majority of dentists in our study reported using both CAM and conventional therapies in a complementary fashion for the treatment of MSD. Including CAM education into the dentist curriculum can increase students' awareness of preventing MSDs. Future research that looks at incorporating CAM therapies, such as yoga, into dental programs can assess their effectiveness by evaluating dentists' musculoskeletal pain once they are in private practice. Incorporating ergonomic education and reinforcing it in clinics may also be successful in preventing MSDs from occurring. Seminars, workshops, and continuing education courses for practicing dentists can be used to educate those who have not had the advantage of learning ergonomics and CAM at dental schools.

\section{CONCLUSION}

Dentists with work-related pain who used CAM therapies reported they had greater overall health, career satisfaction, were able to work the hours they wanted and felt more secure and happy in their jobs when compared to conventional therapy users. Incorporating CAM education into the dental curriculum can increase students' awareness of developing and preventing MSD. The current trends of integrative medicine/dentistry and holistic attitude of dentist towards patient care and themselves dictate newer approaches in the improvement of the care. Dentists should practice yoga or other stretching exercises at workplaces (just for ten minutes) and use relaxation techniques to reduce stress and risks of injury on the job. Information on CAM can easily be obtained through the vast electronic and printed literature or professional CAM users located in different parts of the world.

\section{ACKNOWLEDGEMENT}

I am thankful to my mentors Dr. D.J. Bhaskar and Dr. Mary Suvarna for their guidance, kind cooperation and blessings. Their position will remain high in my heart throughout my life.

\section{REFERENCES}

1. Babar-Craig H, Banfield G, Knight J. Prevalence of back and neck pain amongst ENT consultants: National survey. J Laryngol Otol. 2003;117(12):979-82, http://dx.doi.org/ 10.1258/002221503322683885.

2. Hagberg M, Wegman DH. Prevalence rates and odds ratios of shoulder-neck diseases in different occupational groups. Br J Ind Med. 1987;44(9):602-10.

3. Kumar SP, Kumar V, Baliga M. Work-related musculoskeletal disorders among dental professionals: An evidencebased update. Indian J Dental Educ. 2012;5(1):5-12.

4. Holmström EB, Lindell J, Moritz U. Low back and neck/ shoulder pain in construction workers: Occupational workload and psychosocial risk factors. Part 1: Relationship to low back pain. Spine. 1992;17(6):663-71, http://dx.doi.org/10.1097/00007632-199206000-00005.

5. Hayes MJ, Smith DR, Cockrell D. Prevalence and correlates of musculoskeletal disorders among Australian dental hygiene students. Int J Dent Hygiene. 2009;7(3):176-81, http://dx.doi.org/10.1111/j.1601-5037.2009.00370.x.

6. Murtomaa H. Work related complaints of dentists and dental assistants. Int Arch Occup Environ Health. 1982;50(3):231-6, http://dx.doi.org/10.1007/BF00378085.

7. Shugars D, Miller D, Williams D, Fishburne C, Srickland D. Musculoskeletal pain among general dentists. Gen Dent. 1987;4:272-6.

8. Rolander B, Bellner A. Experience of musculo-skeletal disorders, intensity of pain, and general conditions in work - The case of employees in non-private dental clinics in a county in southern Sweden. Work. 2001;17:65-73.

9. DeForge DH. Physical ergonomics in veterinary dentistry. J Vet Dent. 2002;19(4):196-200.

10. Yamalik N. Musculoskeletal disorders (MSDs) and dental practice. Part 2. Risk factors for dentistry, magnitude of the problem, prevention, and dental ergonomics. Int Dent J. 2007;57(1):45-54. 
11. Crawford L, Gutierrez G, Harber P. Work environment and occupational health of dental hygienists: A qualitative assessment. J Occup Environ Med. 2005;47(6):623-32, http://dx.doi.org/10.1097/01.jom.0000165744.47044.2b.

12. Williams K, Abildso C, Steinberg L, Doyle E, Epstein B, Smith D, et al. Evaluation of the effectiveness and efficacy of Iyengar yoga therapy on chronic low back pain. Spine. 2009;34(19):2066-76.

13. Gupta D, Bhaskar DJ, Gupta RK, Karim B, Gupta V, Punia H, et al. Effect of Terminalia chebula extract and chlorhexidine on salivary $\mathrm{pH}$ and periodontal health: 2 weeks randomized control trial. Phytother Res. 2014;28(7):992-8, http://dx.doi.org/10.1002/ptr.5075.

14. Fautrel B, Adam V, St-Pierre Y, Joseph L, Clarke AE, Penrod JR. Use of complementary and alternative therapies by patients self-reporting arthritis or rheumatism: Results from a nationwide Canadian survey. J Rheumatol. 2002;29(11):2435-41.

15. Werner RA, Franzblau A, Gell N, Hamann C, Rodgers PA, Caruso TJ, et al. Prevalence of upper extremity symptoms and disorders among dental and dental hygiene students. J Canadian Dent Assoc. 2005;33:123-31.

16. Akesson I, Johnsson B, Rylander L, Moritz U, Skerfing S. Musculoskeletal disorders among female dental personnel clinical examination and a 5-year follow-up study of symptoms. Int Arch Occup Environ Health. 1999;72(6):395-403, http://dx.doi.org/10.1007/s004200050391.

17. Finsen L, Christensen H, Bakke M. Musculoskeletal disorders among dentists and variation in dental work. Appl Ergon. 1998;29(2):119-25, http://dx.doi.org/10.1016/ S0003-6870(97)00017-3.
18. Leggat PA, Kedjarune U, Smith DR. Occupational health problems in modern dentistry. Ind Health. 2007;45(5): 611-21, http://dx.doi.org/10.2486/indhealth.45.611.

19. Nermin Y. Musculoskeletal disorders (MSDs) and dental practice: Part 1. General information terminology, aetiology, work-relatedness, magnitude of the problem and prevention. Int Dent J. 2006;56:359-66, http://dx.doi.org/ 10.1111/j.1875-595X.2006.tb00342.x.

20. Sherman KJ, Cherkin DC, Hawkes RJ, Miglioretti DL, Deyo RA. Randomized trial of therapeutic massage for chronic neck pain. Clin J Pain. 2009;25(3):233-8, http://dx.doi.org/10.1097/AJP.0b013e31818b7912.

21. Sherman KJ, Cherkin DC, Erro J, Miglioretti DL, Deyo RA. Comparing yoga, exercise, and a self-care book for chronic low back pain: A randomized, controlled trial. Ann Intern Med. 2005;143(12):849-56, http://dx.doi.org/ 10.7326/0003-4819-143-12-200512200-00003.

22. Artus M, Croft P, Lewis M. The use of CAM and conventional treatments among primary care consulters with chronic musculoskeletal pain. BMC Fam Pract. 2007;8:26, http://dx.doi.org/10.1186/1471-2296-8-26.

23. Brinkhaus B, Witt CM, Jena S. Acupuncture in patients with chronic low back pain: A randomized controlled trial. Arch Intern Med. 2006;166(4):450-57, http://dx.doi.org/10.1001/archinte.166.4.450.

24. Rosenberg EI, Genao I, Chen I, Mechaber A, Wood JA, Faselis ChJ, et al. Complementary and alternative medicine use by primary care patients with chronic pain. Pain Med. 2008;9(8):1065-72, http://dx.doi.org/10.1111/ j.1526-4637.2008.00477.x. 